\title{
Teacher-practitioner research inquiry and sense making of their reflections on scaffolded collaborative lesson planning experience
}

\author{
Sally B. Gutierez ${ }^{1,2}$ (i)
}

Correspondence: sbgutierezupd@ snu.ac.kr

${ }^{1}$ Department of Biology Education, College of Education, Seoul

National University, Seoul, Republic of Korea

${ }^{2}$ University of the Philippines National Institute for Science and Mathematics Education Development, Diliman, 1101 Quezon City, Philippines

\begin{abstract}
Capacity building usually follows any initiative. This also applies to education especially after curriculum reforms. This is to equip teachers with enough skills that would make them align their practices to the news standards. The focus of this qualitative study was to articulate the sensemaking and practitioner research inquiry of the teachers on their scaffolded collaborative lesson planning as one of the components of their on-going professional development (PD). Data were obtained from the formal and informal reflections of the teacher study groups who collaboratively worked on an inquiry-based lesson for elementary school classes. These data were audio and video-recorded, transcribed in verbatim and iteratively analyzed using the constant comparison method of the grounded theory. A priori codes from literature and the objectives of the PD program were merged with the data-driven codes to form the themes which established the findings on how the teachers as practitioner researchers made sense of their collaborative lesson planning experience and its implications to their professional identity. Final codebook were created, validated by an outside expert, and was used to code the anonymized transcripts. Results showed that three themes emerged which represented the teachers' sensemaking of their scaffolded collaborative PD: 1) cognitive and social process of adult learning; 2) collective ownership of learning resulting to professional commitment; 3) research-based experiential learning. It was also found out that their scaffolded collaborative lesson planning experience created impact on their teaching profession as they articulated the activity as a venue for: 1) mutual leadership leading to increased feeling of effectiveness; and 2) improved teacher professional identity.
\end{abstract}

Keywords: Collaboration, Lesson planning practice, Practitioner research, Professional development, Practitioner research

\section{Introduction}

Historically, there exists a long-standing notion that research is restricted only to the academe, particularly the universities. However, research-based professional development $(\mathrm{PD})$ is becoming popular with the recognition that teachers can be effective research practitioners who utilize their lessons as research objects (Gutierez 2016). Thus, the term 'research lessons' (Dudley 2014) was coined as a stimulus of inquiry and an epistemic tool in which teachers explore their own pedagogical practices in an

( ) The Author(s). 2019 Open Access This article is distributed under the terms of the Creative Commons Attribution 4.0 International License (http://creativecommons.org/licenses/by/4.0/), which permits unrestricted use, distribution, and reproduction in any medium, provided you give appropriate credit to the original author(s) and the source, provide a link to the Creative Commons license, and indicate if changes were made. 
authentic professional learning environment. With the growing recognition of teachers' capacity to become practitioner-researchers, PD models such as the lesson study are geared towards building positive and engaging reflective practices in a collaborative and trusting environment (McArdle and Coutts 2010). In essence, practitioner research is embedded in the teachers' daily routines and their inquiry is contextualized from students' responses in order to hypothesize and explore effective and meaningful instructional practices.

In education, practitioner inquiry aims for improving and gaining understanding on how educational theory and practice can be orchestrated to yield productive and beneficial outcomes. It can be equated to action research, which is directed towards enhanced teacher knowledge and skills in order to become responsive to students' learning needs. It is essentially for teachers' regular professional inquiry, which becomes meaningful when they focus on their classroom setting (Raphael et al. 2014) in the process of unraveling the knitted instructional complexities and explore their willingness to adapt to the emerging practices of the teaching and learning process (Loucks-Horsley et al. 1987).

Practitioner research models can be traced back to those pioneered by Stenhouse (1975) which gained attention towards research-engaged teaching practice. It is a PD model which becomes effective when structured to focus on students' learning in a collaborative, sustainable and reflective process (Darling-Hammond and McLaughlin 1995; Lieberman and Miller 2014). According to Loucks-Horsley et al. (1987, p. 1), "supporting the continual development of teachers is critical to attracting and keeping the best and brightest people in the profession." Supporting teachers yield professional growth, which will impact student learning and achievement. Thus, the "interrelationship between student achievement, teacher quality, and professional development are interdependent" (Zepeda 2011, p. 10).

Much as practitioner inquiry is a promising PD, teachers' commitment and engagement are usually compromised. Considering the demands of the teaching profession, doing research can be an added burden into the professional lives of teachers (Macintyre 1997). More often, teachers tend to focus more on instruction rather than on the complexities of doing research. Moreover, understanding the real protocols of research work, lack of skills, and the insufficient time of doing research are the other challenges teachers face while teaching and doing research (Davies 2017). Thus, teachers need the collegial effort and an organized collaborative network in order to share good practices and discuss the impacts of new existing standards as well as express their opinions on their students' teaching and learning difficulties. Collegial effort includes recognition of the roles of co-teachers, administrators and teacher educators and researchers so as to gather multiple perspectives on the gaps between educational theory and practice.

While there is a growing interest to design teacher practitioner research inquiry as a sustainable PD, this paper reports the result of an attempt to engage teachers in this activity as they are scaffolded by university education specialists. As professional scaffolds, the university education specialists guided the teachers in constructing research lessons of which they examined their impacts based on students' responses. Specifically, this study investigated the following:

- As practitioner researchers, how did the teachers make sense of their reflections on scaffolded collaborative lesson planning experience? 
- Based on their reflections, what implications did the scaffolded collaborative lesson planning had on the teachers' professional practice?

\section{Theoretical framework}

Pivotal to gaining insights about the connections of theory and practice is understanding of the nature of their experience. In teacher PD efforts, practitioner research is becoming popular in recognition of the teachers' authentic data which comes directly from their classrooms (Dimmock 2016). According to Johnston et al. (2019), considering the multiple perspectives that educators bring into a practitioner inquiry activity, their curricula become socially and culturally relevant when they are immersed and become active in the research process. In this study, this idea was considered giving credits to the teachers' in-depth understanding of their classroom scenarios which can be viewed as areas of improving their instructional practices.

Practitioner research resembles the concept of Communities of Practice (CoP) which embodies the framework of social learning. In CoP, situated learning occurs when members engage in finding solutions to their problems and knowledge is distributed among individuals with varying levels of expertise (Lave and Wenger 1991a, b; Hutchins 1995). As such, scholars regard the authentic and on-going nature of knowledge construction in CoPs as a venue for teachers to develop their professional skills (Brooks 2010). As it fosters critical reflection, it can lead to transformative learning as it facilitates changes in teachers' beliefs and practices (Herbers et al. 2011). Thus, PD activities such as practitioner research and CoPs are lauded for their potentials for transformative learning as they highlight collaboration, teacher-driven inquiry and agency (Carpenter 2015).

This study also considers the adult learning theory, which highlights experiential and self-directed learning. Experiential learning, which is considered to be the core of professional learning is said to be socially constructed (Ben-Peretz et al. 2010). Thus in this study, teachers conduct research that is socially situated and constructed in the process of iterative inquiry through sharing of ideas and practices with others. This is to support professional meaning-making as teachers become accountable for their own learning and become faithful in implementing the products of their collaborative inquiry (Cochran-Smith and Lytle 2009). Considering the impact of self-directed learning in a practitioner research-based $\mathrm{PD}$, teachers, who are the key players are empowered to identify their learning needs, critically appraise new information and reflect and express their views on their learning process.

\section{Valuing practitioner research-based professional development}

Traditionally, teachers' PD initiatives appear ineffective in creating impact on their practices due to negligence of PD models to focus on their specific learning needs. Products of PD would then bring no impact but rather to the lack of congruence between the increasing demands for students' complex twenty-first century skills and teacher competencies. Acknowledging these shortcomings, researchers have been constantly advising PD developers to involve teachers in the planning and enactment of PD practices (Hirsh and Hord 2010; Kale et al. 2009). Additionally, it should promote a deepened collaborative reflection that embraces the nature of action research (Lopez- 
Pastor et al. 2011) and create a dialogue about "expectations, struggles and questions about teaching and learning" (Martin and Scantelbury 2009, p. 127).

Shifting away from the traditional PD places the power of professional learning into the hands of the teachers so that they assume the role of both practitioners and researchers in the classroom. It allows the necessity for a create job-embedded professional inquiry that makes them question and reflect on their own practice which will eventually enhance their professional identity and regard the teaching profession as a scholarly endeavor (Dana and Yendol-Hoppey 2009). In light of establishing teacher researcher identity, it negates the notion that "... teachers are primarily technicians; the goal of teacher learning initiatives is to make teachers more faithful implementers of received knowledge and curriculum; subject matter is a more or less static object to be transmitted from teachers to students" (Cochran-Smith and Lytle 2009, p. 2).

The emergence of practitioner research primarily aims to empower teachers to take ownership and confidence on their work. However, with the demands of research and the unfamiliarity of its nature, university education researchers are tapped to become professional scaffolds to support teachers in their journey of understanding the broad and dynamic nature of the teaching profession. Their presence as experts in a group of researchers emphasizes the importance of knowledgeable others for the deepening of the inquiry process (Gallagher et al. 2011). Their presence establishes negotiated agreement when multiple and diverging opinions arise. As teachers need knowledgeable sources outside their immediate circle (Feiman-Nemser 2001, p. 1042), school-based teachers and university researchers could bring into the table of educational research credible outcomes from both practical knowledge and academic knowledge (McLaughlin 2004).

\section{Scaffolding the teacher researcher practitioner learning community}

In order to slowly eliminate the gaps between theory and practice, the involvement of teachers in a practitioner research-based professional development was given emphasis. Acknowledging the fact that teachers are also learners with diverse set of knowledge, attitudes, and beliefs, they too need advisers in order to optimize their learning process in a research-based practitioner research. Thus, creating a learning community consisting of a group of teachers with shared goals can lead to a wider range of collaboration (van Es 2012). This can be extended to a collaborative reflection about the theory and practice; the theory may come from the experts and the practice may come from the daily routines of the teachers and other issues about their day-to-day teaching experiences direct from the classroom setting (Cochran-Smith and Lytle 1999; DarlingHammond and Sykes 1999).

Scaffolded teacher learning community is an environment with elements of collegiality and collaboration (Servage 2008; Wheelan and Tilin 1999). It brings about each member's expertise, which disperses the social and intellectual accountability in the process of helping each other grow in practice (Koellner-Clark and Borko 2004). The community is shaped by understanding individual differences, beliefs, knowledge and practices. To foster classroom inquiry, each take turns in posing questions related to teaching and using evidence to make claims and to build a discourse aimed towards "productive conversations" (Borko et al. 2008, p. 421). In order to dismiss the teachers' reluctance and introversion in sharing their work, each must be made comfortable 
through collegial treatment in the learning environment (Lieberman and Pointer Mace 2010; Skerrett 2010). As Campbell suggests:

Through engaging in discussion and joint exploration, a range of perspectives can be brought to bear on a problem, leading perhaps to an enriched understanding of the issues. Also, there will be a range of expertise that can be called into play in pursuit of a solution, bringing the possibility for the members of the group to learn new skills. The potential for cross-fertilization of ideas and shared planning and development may lead to greater creativity and productivity (Campbell et al. 2003, p. 7).

The strength of teacher learning community is the collective endeavor in the development of collective knowledge that is generated in a shared environment where intellectual growth is highly regarded while maintaining a mutual trust and respect for multiple perspectives. Teachers' inquiry is scaffolded by mentors who act as co-learners and collaborative colleagues and co-creators of knowledge for teaching (Beck and Kosnik 2002). Inquiry-driven learning is established in a community that centers on personal practice, which "involves a knowledge of teaching about teaching and a knowledge of learning about teaching and how the two influence one another," (Loughran 2008, p. 1180).

\section{Methodology}

\section{Structure of the PD program}

The present study was conceptualized from an on-going school-based PD practitioner research PD designed for elementary school science teachers. This PD activity was particularly designed to update and align the teachers' lesson planning practices towards inquiry-based teaching. Harnessing the power of collaboration, the PD activity introduced teachers to collaborative lesson planning and development in a seminarworkshop. In the seminar, the teachers were oriented towards collaborative lesson planning and its advantages. They were also exposed to inquiry-based sample lessons where they were provided opportunities for experience the lesson modeled to them by science education specialists who acted as facilitators. During the modeling session, the facilitators requested them to act as students who are doing the activity in an actual classroom. Lesson processing followed the lesson implementation by asking them to identify the features of inquiry that were embedded in the lesson. Both content and pedagogical knowledge were addressed during the processing of the lesson.

The modeling session was followed by a workshop session which asked them as a Grade level team to collaboratively design an inquiry-based lesson. They were asked to identify the most challenging topics to teach in their current curriculum and collaboratively draft an inquiry-based lesson. At this stage of the workshop, the science education specialists were available anytime they needed assistance or confirmation in both content and pedagogical knowledge. They were also encouraged to try-out their lesson especially when their lessons required some hands-on activities. These were then finalized for presentation to the other teams and the facilitators. Processing also followed which identified the features of inquiry that were embedded in the lesson and constructive critiquing of the lesson. Teams were asked to document on the suggestions and comments of other teams which will be used as guides for the revision of their 
lessons. These lessons were agreed to be implemented to actual classrooms which were observed and constructively critiqued based on students' responses. Two cycles of lesson implementation were done but with two different teachers implementing it. The lesson of the first cycle was from the output of the seminar-workshop; the second cycle was from the revised lesson after the first implementation.

Starting from the seminar-workshop, the whole PD process took one school year. In all of the stages of the PD process, teachers were asked of both formal and informal reflections which were documented using audio- and video-recordings. Teachers' reflections comprised of their insights on the inquiry-based teaching, collaborative lesson planning, and on their involvement in the practitioner research. Informal reflections were from facilitators' informal questions while formal reflections used open-ended questions which asked them to write their responses. These reflections were transcribed and served as the source of inquiry served as the data of this study.

\section{Participants}

Elementary science and mathematics teachers from the school with the largest population of elementary students in Metro Manila in the Philippines were the participants of the study. This was purposively chosen with much consideration on the PD design. To specify, each of the lessons will be implemented twice so there is a need to have enough classes for observations. Teachers were grouped into two large groups: science and mathematics group. Each of these large groups were subdivided into smaller groups consisting of five teachers who were representative of each Grade level from Grades 16 usually referred to as the study group. Considering the school-based design of this $\mathrm{PD}$, each of the grade levels was equally represented to give a general picture of the whole school.

In this study, the science group of teachers was the main participants to whom the author was involved as a facilitator in the seminar-workshop and in the follow-through activities. Nine years was the average length of teachers' teaching experiences with a minimum of five months and a maximum of over 30 years. Most of the participants were females especially those in the lower grade levels (Grades 1-3) but this selection was not done in purpose. As most of the teachers in the chosen school are required to attend in-service PDs during their summer break, the teacher-participants in this PD activity were the ones who were available to represent their grade levels during the scheduled date of seminar-workshop.

During the follow-through periods, each member of the study group was required to attend and observe the lesson implementation and took notes on the effectiveness of the lesson based on students' responses. In few times during the implementation and observation, the science coordinator of the school joined the group and participated during the debriefing session, which is focused on reflection on the lesson. At least two facilitators were present during the implementation and observation to ensure valid amount of content ideas during the constructive critiquing of both science content and pedagogical approaches.

As mentioned in the rationale, this research was conceptualized by the researcher (who acted as a facilitator) in consideration to the robust amount of teachers' reflections as one of the components of the teachers' PD activity. These reflections were 
primarily obtained from audio and video recordings which were triangulated using formal and informal reflective conversations. To avoid bias, the final transcripts were verified by the facilitator during the seminar-workshop who also acted as the co-observer during the lesson implementation stages. Iterative coding and re-coding process involved outside experts which ensured the credibility of the final themes which were used in the final analysis of data.

\section{Research design}

This study utilized a qualitative research design. As the study was concerned on the teacher-practitioner inquiry and sense making of their scaffolded collaborative lesson planning experience in their current PD, all their reflections were closely documented and analyzed. The large amounts of qualitative data from the audio- and videorecordings were transcribed in verbatim and subsequently open-coded to generate the common themes. This was followed by axial coding in order to generate the themes on how the teachers made sense of their collaborative lesson planning activity and what are the implications of their sense making to their teaching profession.

\section{Data analysis and interpretation}

Most of the data were obtained from audio-and video-recordings of the teachers' formal and informal reflections from both the seminar-workshop and the school-based implementation of the lesson to actual classrooms. All these data were transcribed in verbatim, coded, and thematically analyzed using the constant comparison method of the grounded theory (Strauss and Corbin 1990) in order to explicate the teachers' sense making of their collaborative lesson planning experience. Due to the bilingual mode (English-Filipino) of reflection, all utterances in Filipino were translated by the author. Combined inductive and template coding was done to the a priori and data driven codes which formed the final codebook and the themes. A priori codes were based on existing literature on the positive impacts of collaboration as a teachers' PD and partially on the rationale of current PD program. These were the subjected to outside expert validation and all diverging codes were discussed to finally establish the consensus and the final codes and themes. Recoding of the entire transcripts was done after the validation of the final codes and themes. Representative quotations from both the formal and informal individual reflections were used to support the teachers' sense making of their PD activity and its impact on their teaching profession.

\section{Research ethics}

As specified that the rationale of this study emerged from the reflective data about the teachers' collaborative lesson planning experience, the teachers' assents were sought after the seminar-workshop and before their lesson implementation. In the assent forms, the teachers were informed that all of their formal and informal reflections from both the seminar-workshop and the lesson implementations will be used as data in the study. They were informed that data transcripts will be the primary data for analysis which will be kept by the author. They were also informed that pseudonyms will be used in the final transcripts to be subjected for verification, data analysis, and interpretation. 


\section{Findings}

This qualitative study explored how the teachers, as practitioner researchers made sense of their scaffolded collaborative lesson planning experience which was introduced to them in seminar-workshop and school-based implementation as a yearlong PD. Harnessing the advantages of practitioner research, the teachers were oriented on how to use their lesson plans as research objects in this study. Thus, their lesson plans which were the primary output in the scaffolded collaborative lesson planning were labeled as 'research lessons' which were subjected to constructive critique. As an introduced mode of lesson planning, the teachers were asked to formally and informally reflect on this and results showed that based on their reflections, three themes emerged which represented the teachers' sensemaking of their scaffolded collaborative PD: 1) cognitive and social process of adult learning; 2) collective ownership of learning resulting to professional commitment; 3) research-based experiential learning. In the process, teachers faced challenges on the collaborative lesson planning but with the help of the experts, these challenges were slowly addressed. Thus, each of the study groups involved in this $\mathrm{PD}$ as well as in this qualitative study eventually became various microsystems who collaboratively worked together with calmness, support and productive engagement. Open communication provided the venue to look into each other's knowledge lens, to deepen their understanding, and to explore the intricacies of others' perspectives against their own. Moreover, based on their reflection, the scaffolded collaborative lesson planning experience created impact on their teaching profession as they articulated the activity as a venue for: 1) mutual leadership leading to increased feeling of effectiveness; and 2) improved teacher professional identity.

\section{Cognitive and social process of adult learning}

As practitioner researchers, the teachers made sense of their scaffolded collaborative lesson planning as a cognitive and social process of adult learning. Their direct engagement in their research lessons transformed the superficial learning in a traditional PD into "a learning culture in which staff work together to understand what appears to work and why" Brown \& Zhang (2016, p. 781). With shared values, goals and visions stated in their research lessons, their scaffolded collaborative lesson planning experience enhanced their social interactions where knowledge construction was collaboratively undertaken in a situated learning environment. This can be exemplified based on Teacher Mina's reflections when she said, "it pays to have an interaction with other teachers especially those who already have experience in teaching the lesson. As a new teacher, I may have similar encounters in the future ... hmm and as a member of this group, I already know how to address those similar problems." In this reflection, it can be understood that she articulated her participation to the scaffolded collaborative lesson planning to be relevant and beneficial to her classroom in the future. Moreover, Teacher Jeff stated that, "I did not know that each student's responses on the lesson gives meaning regarding how the lesson was constructed and how it was delivered ... but because we are dealing with large number of students in our classes, we fail to see these. In our study group, other observers were able to notice them and together we can learn from those." In this statement, it is clear that Teacher Jeff gave credits into the role of collegiality from between them and their mentors especially during the collaborative 
critiquing of their lessons as a scholarly and critical inquiry into their own practice. With their direct engagement in the analysis of their research lessons, their professional learning was legitimized and even augmented through the scaffolding of the experts.

Considering the lessons as research objects, the collaborative lesson planning experience served as a PD which fostered cognitive and social adult learning process during the collaborative brainstorming and predicting the results based on students' responses. Moreover, as their products of collaborative inquiry were translated into their final research lessons, teachers were able to integrate their collective ideas into their instructional practices. In the process, they were able to see evidences on how their prior knowledge can be transformed into a new knowledge grounded on collegial coconstruction of knowledge. Scaffolded collaborative lesson planning therefore can serve as a ground for teacher practitioner researchers where they can cultivate a common understanding that shifts solitary learning into a social activity where experiences are shared through social interactions.

\section{Collective ownership of learning resulting to professional commitment}

Based on the teachers' reflections, their active participation, collegial communication, and continuous acknowledgement on their expertise as research practitioners were the key ingredients to their commitment in the scaffolded collaborative lesson planning. In the reflective statement by Teacher Nida who acted as a team leader in the Grade 3 study group said, "working as a group guided by the experts was beneficial for us to build solid interpretation of our students' responses." This statement recognized the role of each teacher which established the foundation of the best practices which was later on incorporated in their research lessons. With a focus on students' responses, they were bound together by clear goals of understanding the complex and diverse nature of every learner. Moreover, in consideration of the scaffolding efforts of the experts, theoretical and practical knowledge were fused which were later on reflected in their lesson plans. In response to Dimmock's (2016) proposal on the inclusion of research as a component in any professional learning community, teachers in this study validated this through their formal and informal reflections.

Analysis also revealed that teachers gave credits to their individual knowledge as equally important as the baseline for the combined products of their inquiry process. In fact, Teacher Grace mentioned, "we all have different approaches to teaching base on our experience but each share good insights to obtain all our best practices." Based on this statement, it was implied that Teacher Grace was giving value on the role collaboration in their lesson planning practice. Their individual knowledge served as one of the reasons to strengthen their collaboration with an aim for consensus during lesson planning. Moreover, the time they spent working collaboratively on their lessons were particularly valuable as they gained collective ownership on them-a stark contrast compared to their traditional isolated practices for lesson planning. This supports the concept of knowledge-sharing aspect which was claimed to facilitate individual professional learning (Dalby 2019).

\section{Experiential learning provided suitable prompts for reflective practice}

Over the course of 12 months, the study groups were keen to provide themselves with the robust opportunity to review critical situations that were considered as areas of 
experiential learning. Discussions were dominated with topics such as identifying instructional problems, reviewing and connecting theoretical knowledge to actual experiences; all of which utilize evidences for a richer and deeper reflection. Scaffolded by the experts, the teachers made all decisions from the problems that they want to assess and the instructional solutions to be implemented. According to Teacher Chris, "I would not know all these if not for the reflection of this group ... and one thing I appreciate about this group is that we just don't focus on the problem but also on the good points that were observed." It is clear that through their individual experiences, they were able to build a common ground and shared the language of inquiry direct from experiences. Moreover, it can also be deduced that the structured debriefings for post-lesson discussions was crucial elements in the PD program. The availability of discussion points, which was prompted by the direct observations of each member, is a means for keeping the experience alive. The teachers continuously became convinced, as they perceive the classroom experience to bring unique lessons to which inquiry can be done. As they are hands-on in the inquiry procedure, their strong commitment for a gradual change in practice can thus be expected. This supports Wiliam (2010) in his argument that changing a teacher's knowledge or belief is insufficient unless teachers make their commitment to change their practice.

\section{Implications to the teachers' professional practice}

As teacher education systems in the world are increasingly interested in building teacher capacity for a practitioner research involvement, the PD program employed in this study was designed to empower teachers and spark their own initiative to strengthen their capacity for collaborative learning that will impact their professional lives. Analysis on their reflections resulted to their collective efficacy which created impact on their professional lives resulting to their increased regard to their professional practice such as increased feeling of effectiveness while putting value to collective leadership, and improved teacher identity.

\section{Increased feeling of effectiveness while putting value to collective leadership}

Aligned with the objective, the conceived activities of this PD program was inherently interactive; utilizing the integrated and iterative process where new insights were made available in building new knowledge which were made explicit and negotiable. This fostered a healthy dialogue as the members of each study group collaborate with each other towards finding similar or coordinated ways to conduct exploration of their teaching practices. As the teachers valued the information provided by the experts, their previous experiences heavily influenced the reflective process the intellectually stimulating equal knowledge sharing. This made them recognize the value of collective leadership and commitment to contribute for each other's improvement of their areas of expertise. This can be traced back from the reflective statements of the following teachers:

Teacher Hannah: "We have the reason why we are doing this ... we know each of our lesson will create impact in every child's life and it's our responsibility to help them."

Teacher Randy: "Together we assess the gaps of our teaching practice ... since we each bring a piece of what we know, we are encouraged to work as a group." 
One factor that seems worth mentioning is the sustained trust that the teachers established while in their research group. Through this, building of positive relationships where built which resulted to their willingness to take risks and continuously come together to try out activities. As such, it was revealed from their reflections that their scaffolded collaborative lesson planning resulted to collective leadership which is aligned to Childs-Bowen et al. (2000, p. 28) claim that, "teachers are leaders when they function in professional learning communities to affect student learning; contribute to school improvement; inspire excellence in practice; and empower stakeholders to participate in educational improvement."

\section{Improved teacher professional identity}

In conjunction with the sense of shared ownership of the teachers as one of their perceived impacts of the scaffolded PD activity, the teachers put value into what they achieved. Two teachers mentioned:

Teacher Aila: "I appreciate the how the dynamics of our lesson planning ... everyday is an achievement"

Teacher Josie: "We now have a model lesson, something what we can be proud of."

Teacher Nympha: ... the fact that we decide on our own ... but you (the experts) are always there to assist ... that motivates us.

Collective agency is usually enacted when "coaches exert influence, make choices, and take stances in ways that affects their work and their professional identities" (Hokka et al. 2017, p. 38). Going back to the PD's objective of teacher capability building by exploring the potential of scaffolded collaborative lesson planning, recognizing the teachers' skills practitioner researchers was an investment to their framing of their actions in the future. With a focus on their professional practices, they became open to accommodate new learning opportunities which may influence their existing knowledge and beliefs on the traditional and solitary lesson planning practices. Through collaboration, the products of their learning were formed from their individual inputs, thereby making them 'agentic' professionals (Etelapelto et al. 2015; Tam 2015).

\section{Discussion and conclusion}

Models of professional development suggest that external support for teachers is essential to create change (Stoll et al. 2006). Sustaining this climate in the demanding teaching roles is a complicated task, as it requires purposeful efforts of joint compromise and teacher commitment. In this study, it is evident that the teachers did not show resistance but rather they saw the PD to offer enhanced opportunities for individual and collective learning. Collaborative lesson planning, which is the real essence of their PD, was taken positively and based on their reflections, they expressed their ownership in the development of their professional identity. Taken together, the scaffolding role of the experts empowered the teachers, which amalgamated the collective efficacy of the study group. Moreover, their discussions were facilitated by the theoretically inclined peers whom they treated as colleagues in the process of identifying and planning what 
particular actions to do as a solution to their apparent challenges in their instructional practices. As they were given opportunities to express their ideas, the teachers were empowered to exercise leadership over their professional development, which leads to recognition of the feeling of effectiveness. Seeing the experts as collaborators, this PD activity supported the idea of creating a community from a range of people from inside and outside the school that can mutually work together to enhance learning (Stoll et al. 2006).

In the Philippines, collaborative lesson planning is an emerging practice for the teachers. Thus, in this study, the focus of analysis was the reflections of the teachers regarding this practice. Results showed that the teachers made sense of this practice as a source of interdependency which became the foundation for their commitment. Interdependency which can be associated to collaboration was observed as the key to collective leadership and increased professional growth.

Reiterating reflections as the data source, this served as an outlet where teachers were able to voice out their opinions, express their observations on what is going on during their collaborative inquiry (Mason 1993). With experts' scaffolding, they were guided on which tangible actions they will take in order to take control of the changes in classroom practices. The social exchanges did not only interpret meaning but more so to establish a continuous interaction that built productive relationships. Thus, collaborative lesson planning as a component of teacher PD can be a foundation for the establishment of a "culture of inquiry" through "team teaching and facilitation of practitioner inquiry" (Grimmest, 1998, p. 264).

As teacher-practitioners, sense making the collaborative lesson planning based on the teachers' reflections, the process "broke the traditional authority relationships" allowing the study groups to take initiatives of their actions at the same augmenting the ideas whenever necessary (Juutilainen et al. 2018, p. 121). With enough recognition on the value of the individual teacher's knowledge, hesitation was eliminated which made the inquiry process an experiential learning. Moreover, scaffolding which gave them the opportunities to reflect on personal practices, observe colleagues and participate in a mediated dialogue, the teachers perceived safe compromise and took charge of their actions giving credits to their own accounts on the possible areas of instructional improvement. Collaborative lesson planning therefore became an effort of looking into the lens of their own teaching practices in order to facilitate 'learning how to learn' while taking the role as both a teacher and learner towards understanding the dynamics of their instructional practices (Avalos 2011; Darling-Hammond and McLaughlin 2011).

Considering the argument that teachers' PD should be an intrinsic process of personal growth (Day 1999), this was stirred by collaborative lesson planning which involved parties who were open and willing to comprehend the theoretical underpinnings of the abstract knowledge against experiential knowledge. Their openness to constructive criticism and scrutiny did not limit the extent of their understanding the research implications to the small-scale realities of classroom life. As Pring (2000) said "research should be the servant of professional judgement, not its master" (p. 139). This then supports Cochran-Smith and Lytle (1993, p. 42) conclusions about teacher research as an activity which includes both empirical and conceptual inquiry in their definition and suggest that teacher research may generate both local knowledge and public knowledge: 
local knowledge informing their own practice and potentially benefiting the immediate community of teachers, and public knowledge informing the wider 'community of educators'.

The study concludes that featuring collaborative lesson planning in a teacher PD extends professionalism of teachers in a proximate and non-hierarchical cooperation while maintaining their focus on improving pedagogical practices. While every member of the group took responsibility of particular roles, their varying opinions and freedom to express them in a mediated environment provided the opportunities to gain insights from each other. The current study contributes to the growing research in teacher education by recognizing the potentials of collaborative lesson planning at the same time the researcher roles of teachers given enough scaffolding from outside experts who opened the gateway and broke the gaps of authority relationships. In the long run, the learning community will be able to establish local innovation in their own practices in a climate of trust which will encourage them to experiment their own practice.

Through heightening teachers' awareness of their potentials to become researchers, professional scaffolding is essential as both parties are in the struggle to take part in the community of practice with a unified goal and shared interest. The study can also impact the teacher education sector to reflect on the possibility of re-defining and extending teacher roles as they make evidence-based decisions. Providing space to acknowledge teachers' capabilities instead of creating a dichotomy of roles whether as teachers and academic experts can be a way to enrich teachers' agency and effectiveness. In a decade of curriculum change in the Philippine education curriculum, much research is needed and empowering the teachers to explore their own classrooms can be promising to differentiate knowledge and action from all their in-service trainings that they are tasked to attend. As the study centered on lesson planning as the primary means of teacher collaborative activity and reflective practice, the consultation sessions assured the support and convergence of ideas and collective beliefs as potential routes to uplift the professionalism of teachers as they grow strong ties among themselves and as a result, they may harvest student achievement.

Acknowledgements

I wish to express my gratitude to the teachers who participated in this study as well as the colleagues who supported it. I would like to thank the anonymous reviewers for their helpful suggestions and feedback.

Author's contributions

The author read and approved the final manuscript.

Author's information

Sally Gutierez is a Science Education Associate at the University of the Philippines, National Institute for Science and Mathematics Education Development. She holds a Doctoral Degree in Biology Education from Seoul National University. Her research interests include scientific argumentation, dialogic scaffolding, instructional framing, scaffolding practices in science education, and teacher professional development.

Funding

Not applicable.

Availability of data and materials

The qualitative data set, primarily the informal and formal transcripts are available from the author on a reasonable request. 
Received: 11 August 2019 Accepted: 13 November 2019

Published online: 27 November 2019

\section{References}

Avalos, B. (2011). Teacher professional development in teaching and teacher education over ten years. Teaching and Teacher Education, 27(1), 10-20. https://doi.org/10.1016/j.tate.2010.08.007.

Beck, C., \& Kosnik, C. (2002). Components of a good practicum placement: student teachers' perceptions. Teacher Education Quarterly, 29, 81-98.

Ben-Peretz, M., Kleeman, S., Reichenberg, R., \& Shimoni, S. (2010). Educators of educators: their goals, perceptions and practices. Professional Development in Education, 36(1-2), 111-129. https://doi.org/10.1080/19415250903454908.

Borko, H., Jacobs, J., Eiteljorg, E., \& Pittman, M. E. (2008). Video as a tool for fostering productive discussions in mathematics professional development. Teaching and Teacher Education, 24, 417-436. https://doi.org/10.1016/j.tate.2006.11.012.

Brooks, C. F. (2010). Toward 'hybridised' faculty development for the twenty-first century: blending online communities of practice and face-to-face meetings in instructional and professional support programmes. Innovations in Education and Teaching International, 47(3), 261-270. https://doi.org/10.1080/14703297.2010.498177.

Brown, C., \& Zhang, D. (2016). Is engaging in evidence - informed practice in education rational? What accounts for discrepancies in teachers' attitudes towards evidence use and actual instances of evidence use in schools? British Educational Research Journal, 42(5), 780-801. https://doi.org/10.1002/berj.3239.

Campbell, A., Freedman, E., Boulter, C., \& Kirkwood, M. (2003). Issues and principles in educational research for teachers. Southwell: British Educational Research Association.

Carpenter, J. P. (2015). Unconference professional development: Edcamp participant perceptions and motivations for attendance. Professional Development in Education, 42(1), 1-22. https://doi.org/10.1080/19415257.2015.1036303.

Childs-Bowen, D., Moller, G., \& Scrivner, J. (2000). Principals: leaders of leaders. NASSP Bulletin, 84(616), 27-34. https://doi.org/ $10.1177 / 019263650008461606$.

Cochran-Smith, M., \& Lytle, S. (2009). Inquiry as stance: practitioner research for the next generation. New York: Teachers College Press.

Cochran-Smith, M., \& Lytle, S. L. (1993). Inside outside: teacher research and knowledge. New York: Teachers College Press.

Cochran-Smith, M., \& Lytle, S. L. (1999). Relationships of knowledge and practice: teacher learning in communities. Review of Research in Education, 24, 249-305. https://doi.org/10.2307/1167272.

Dalby, D. (2019). Professional learning through collaborative research in mathematics. Professional Development in Education. https://doi.org/10.1080/19415257.2019.1665571 (Online first).

Dana, N. F., \& Yendol-Hoppey, D. (2009). The reflective educator's guide to classroom research: learning to teach and teaching to learn through practitioner inquiry. Thousand Oaks: Corwin Press.

Darling-Hammond, L., \& McLaughlin, M. W. (1995). Policies that support professional development in an era of reform. Phi Delta Kappan, 76(8), 597-604. https://doi.org/10.1177/003172171109200622.

Darling-Hammond, L., \& McLaughlin, M. W. (2011). Policies that support professional development in an era of reform. Phi Delta Kappan, 92(6), 81-92. https://doi.org/10.1177/003172171109200622.

Darling-Hammond, L., \& Sykes, G. (Eds.). (1999). Teaching as the learning profession: handbook of policy and practice. San Francisco: Jossey-Bass.

Davies, G. (2017). Giving teachers access to research could do more harm than good. EPPI Centre Institute of Education (2016). Available at: http://garydavies.org. Accessed 21 Jan 2017.

Day, C. (1999). Developing teachers: the challenges of lifelong learning. London: Falmer.

Dimmock, C. (2016). Conceptualising the research-practice-professional development nexus: mobilising schools as 'researchengaged' professional learning communities. Professional Development in Education, 42(1), 36-53. https://doi.org/10.1080/ 19415257.2014 .963884$.

Dudley, P. (2014). Lesson study; a handbook. Lesson study UK. Available at http://lessonstudy.co.uk/lesson-study-a-handbook/

Etelapelto, A., Vahasantanen, K., \& Hokka, P. (2015). How do novice teachers in Finland perceive their professional agency? Teachers and Teaching, 21(6), 660-680. https://doi.org/10.1080/13540602.2015.1044327.

Feiman-Nemser, S. (2001). From preparation to practice: Designing a continuum to strengthen and sustain teaching. Teachers College Record, 103(6), 1013-1055. https://doi.org/10.1111/0161- 4681.00141.

Gallagher, T., Griffin, S., Parker, D. C., Kitchen, K., \& Figg, C. (2011). Establishing and sustaining teacher educator professional development in a self-study community of practice: pre-tenure teacher educators developing professionally. Teaching and Teacher Education, 27, 880-890. https://doi.org/10.1016/j.tate.2011.02.003.

Grimmett, P. P. (1998). Reconceptualizing the practice of teacher education: on not throwing out the concurrent model with the reform bathwater. Alberta Journal of Educational Research, 44, 251-267.

Gutierez, S. B. (2016). Building a classroom-based professional learning community through lesson study: Insights from elementary school science teachers. Professional Development in Education, 42(5), 801-817. https://doi.org/10.1080/ 19415257.2015.1119709.

Herbers, M. S., Antelo, A., Ettling, D., \& Buck, M. A. (2011). Improving teaching through a community of practice. Journal of Transformative Education, 9(2), 89-108. https://doi.org/10.1177/1541344611430688.

Hirsh, S., \& Hord, S. M. (2010). Building hope, giving affirmation: learning communities that address social justice issues bring equity to the classroom. Journal of Staff Development, 31(4), 10-17.

Hokka, P., Vahasantanen, K., \& Mahlakaarto, S. (2017). Teacher educators' collective professional agency and identity: transforming marginality to strength. Teaching and Teacher Education, 63, 36-46. https://doi.org/10.1016/j.tate.2016.12.001.

Hutchins, E. (1995). How a cockpit remembers its speeds. Cognitive Science, 19(3), 265-288. https://doi.org/10.1207/ s15516709cog1903_1.

Johnston, K., Hadley, F., \& Waniganayake, M. (2019). Practitioner inquiry as a professional learning strategy to support technology integration in early learning centres: building understanding through Rogoff's planes of analysis. Professional Development in Education. https://doi.org/10.1080/19415257.2019.1647871.

Juutilainen, M., Metsapelto, R. L., \& Poikkeus, A. M. (2018). Becoming agentic teachers: experiences of the home group approach as a resource for supporting teacher students' agency. Teaching and Teacher Education, 76, 116-125. https:// doi.org/10.1016/j.tate.2018.08.013 
Kale, U., Brush, T., \& Saye, J. (2009). Assisting teachers' thinking and participation online. Journal of Educational Computing Research, 41(3), 287-317. https://doi.org/10.2190/EC.41.3.c.

Koellner-Clark, K., \& Borko, H. (2004). Establishing a professional learning community among middle school mathematics teachers. In M. J. Hoines \& A. Fuglestad (Eds.), Proceedings of the twenty-eighth conference of the International Group for the Psychology of mathematics education (Vol. 2, pp. 223-230). Bergen: Bergen University College.

Lave, J., \& Wenger, E. (1991a). Situated learning: Legitimate peripheral participation. Cambridge: Cambridge University Press.

Lave, J., \& Wenger, E. (1991b). Situated learning: Legitimate peripheral participation. New York: Cambridge University Press. https://doi.org/10.1017/CBO9780511815355.

Lieberman, A., \& Miller, L. (2014). Teachers as professionals: evolving definitions of staff development. In L. E. Martin, S. Kragler, D. J. Quatroche, \& K. J. Bauserman (Eds.), Handbook of professional development in education (pp. 67-71). New York: Guilford Press.

Lieberman, A., \& Pointer Mace, D. (2010). Making practice public: teacher learning in the $21^{\text {st }}$ century. Journal of Teacher Education, 61, 77-88. https://doi.org/10.1177/002248710934731.

Lopez-Pastor, V. M., Monjas, R., \& Manrique, J. C. (2011). Fifteen years of action research as professional development: Seeking more collaborative, useful and democratic systems for teachers. Educational Action Research, 19(2), 153-170. https://doi. org/10.1080/09650792.2011.569190.

Loucks-Horsley, S., Harding, C. K., Arbuckle, M. A., Murray, L. B., Dubea, C., \& Williams, M. K. (1987). Continuing to learn: a guidebook for teacher development. Andover: The Regional Laboratory for Educational Improvement of the Northeast and Islands.

Loughran, J. (2008). Toward a better understanding of teaching and learning about teaching. In M. Cochran-Smith, S. Feiman-Nemser, \& J. McIntryre (Eds.), Handbook of research on teacher education: Enduring questions in changing contexts (3rd ed., pp. 1177-1182). New York: Routledge.

Macintyre, D. (1997). The profession of educational research. British education Research Journal, 23(2), 127-140. https://doi.org/ 10.1080/0141192970230202

Martin, S., \& Scantelbury, K. (2009). More than a conversation: using cognitive dialogues in the professional development of high school chemistry teachers. Educational Assessment and Evaluation Association, 21, 119-136.

Mason, J. (1993). Learning from experience in mathematics. In D. Boud, R. Cohen, \& D. Walker (Eds.), Using experience for learning. Buckingham: Society for Research into Higher Education and Open University press.

McArdle, K., \& Coutts, N. (2010). Taking teacher's continuous professional development (CPD) beyond reflection: adding shared sense making and collaborative engagement for professional renewal. Studies in Continuing Education, 32(3), $201-$ 215. https://doi.org/10.1080/0158037X.2010.517994.

McLaughlin, C. (2004). Partners in research: What's in it for you? Teacher Development, 8, 127-136. https://doi.org/10.1080/ 136645304002000020227.

Pring, R. (2000). Philosophy of educational research. Continuum: London.

Raphael, T., Vasquez, J., Fortune, A., Gavelek, J., \& Au, K. (2014). Sociocultural approaches to professional development: Supporting sustainable school change. In L. Martin, S. Kragler, D. Quatroche, \& K. Bauserman (Eds.), Handbook of professional development in education: Successful models and practices, PreK-12 (pp. 145-173). New York: Guilford.

Servage, L. (2008). Critical and transformative practices in professional learning communities. Teacher Education Quarterly, 35(1), 63-77.

Skerrett, A. (2010). "There's going to be community. There's going to be knowledge": designs for learning in a standardized age. Teaching and Teacher Education, 26, 648-655. https://doi.org/10.1016/j.tate.2009.09.017.

Stenhouse, L. (1975). An introduction to curriculum research and development. London: Heinemann

Stoll, L., Bolman, R., McMahon, A., Wallace, M., \& Thomas, S. (2006). Professional learning communities: a review of the literature. Journal of Educational Change, 7, 221-258. https://doi.org/10.1007/s10833-006-0001-8.

Strauss, A. L., \& Corbin, J. M. (1990). Basics of qualitative research: grounded theory procedures and techniques. Newbury Park: Sage.

Tam, A. C. F. (2015). The role of a professional learning community in teacher change: a perspective from beliefs and practices. Teachers and Teaching, 21(1), 22-43. https://doi.org/10.1080/13540602.2014.928122.

van Es, E. A. (2012). Examining the development of a teacher learning community: the case of a video club. Teaching and Teacher Education, 28, 182-192. https://doi.org/10.1016/j.tate.2011.09.005.

Wheelan, S. A., \& Tilin, F. (1999). The relationship between faculty group development and school productivity. Small Group Research, 30(1), 59-81. https://doi.org/10.1177/104649649903000104.

Wiliam, D. (2010). Teacher quality: Why it matters and how to get more of it. Spectator Schools Revolution Conference, March.

Zepeda, S. J. (2011). Professional development: What works. Larchmont: Eye on Education.

\section{Publisher's Note}

Springer Nature remains neutral with regard to jurisdictional claims in published maps and institutional affiliations.

\section{Submit your manuscript to a SpringerOpen ${ }^{\circ}$ journal and benefit from:}

- Convenient online submission

- Rigorous peer review

- Open access: articles freely available online

- High visibility within the field

- Retaining the copyright to your article

Submit your next manuscript at $\boldsymbol{\nabla}$ springeropen.com 